\title{
PENGGUNAAN KAIN TROSO DAN APLIKASI MAKRAME PADA BUSANA READY TO WEAR
}

THE USING OF TROSO TRADITIONAL WOVEN FABRIC AND MACRAME IN READY TO WEAR CLOTHING

Tina Martina, Ursae Pramesvari* dan Santi Ramadhanti

Politeknik STTT Bandung, Kota Bandung, 40272, Indonesia

*Alamat email penulis korespondesi : ursaepramesvari@gmail.com

Tanggal diterima : 15 Februari 2021; direvisi: 29 November 2021 ; disetujui terbit: 3

Desember 2021

\begin{abstract}
Abstrak
Indonesia memiliki kekayaan ragam kain tenun tradisional dari masingmasing daerah. Salah satu daerah yang menghasilkan kain tenun tradisional yaitu Kabupaten Jepara, Jawa Tengah. Kain tenun yang diproduksi di Desa Troso Kabupaten Jepara disebut dengan kain tenun Troso. Dalam upaya memperkenalkan kain tenun Troso, maka disusun rencana penelitian ini yang bertujuan untuk memberikan alternatif baru penggunaan kain tradisional tenun ikat troso dan aplikasi teknik ikat mengikat atau lebih dikenal dengan makrame yang pembuatannya dilakukan secara manual sebagai nilai tambah dalam pembuatan busana. Hasil dari penelitian ini berupa busana ready to wear yang terinspirasi dari Trend Forecasting Fashion tahun 2019-2020 Singularity yang diterbitkan oleh Bekraf dengan tema "Svarga". Metodologi yang digunakan adalah studi literatur dan studi lapangan dalam proses eksperimen pembuatan produk. Kain tenun Troso dan kain tambahan yang akan digunakan memerlukan sifat yang menghasilkan kenyamanan serta kekuatan yang baik bagi penggunanya. Hal tersebut mendasari perlunya dilakukan pengujian untuk kain tenun troso dan kain pendukung. Selain itu aplikasi makrame yang diterapkan akan diproduksi dengan teknik pencelupan zat warna untuk memperoleh hasil gradasi warna. Produk tekstil atau fashion tersebut kemudian dinilai kelayakan harga jualnya oleh masyarakat dengan menggunakan metode kuantitatif berupa kuisioner.
\end{abstract}

Kata kunci : kain tenun troso, makrame, ready to wear

\begin{abstract}
Indonesia has varieties of traditional woven fabrics from each region. One area that produces traditional woven cloth is J epara district, Central Java. Woven fabric produced in Troso village, J epara is called Troso woven fabric. In an effort to introduce Troso woven fabric, this research aims to provide a new alternative to the use of traditional troso woven fabric and the application of macrame techniques which is made by hand as additional value in fashion. The result of this research is ready to wear fashion inspired by Fashion Trend Forecasting 2019-2020 "S ingularity" published by Bekraf with the sub theme "Svarga". The methodology used is the study of literature and exploration in the process of making product experiments. Troso woven fabric and variation fabric to be used require properties that produce comfort for its users. This underlies the need of testing fortroso woven fabrics and supporting fabrics. In addition, the application of macrame that is applied will be produced with
\end{abstract}


dyeing techniques to obtain color gradation. The selling price worthiness of textile or fashion products are then assessed by using quantitative methods in questionnaires.

Keywords :troso woven fabric, macramé, ready to wear

\section{PENDAHULUAN}

1.1 Latar Belakang

Busana dalam dunia fashion dibagi menjadi beberapa jenis busana yang didasarkan atas cara pembuatannya. Jenis busana yang didasarkan atas cara pembuatannya yakni busana haute couture dan busana ready to wear. Istilah busana ready to wear (prêt-à-porter) atau yang dalam bahasa Indonesia berarti busana siap pakai ${ }^{1}$ yang dimana pembeli tidak harus mengukur badan untuk menentukan ukuran busana ataupun kegiatan lain yang menggunakan banyak waktu seperti untuk pemilihan gaya, pemilihan kain, melakukan fitting busana, dan mendapatkan busana dalam suatu waktu tertentu setelah proses-proses tersebut dilalui. Busana ready to wear umumnya dapat digunakan pada berbagai kesempatan; formal, semi formal maupun non formal. Menurut Waddell (2004) dalam buku How Fashion Works: Couture, Readyto-Wear and Mass Production ${ }^{2}$ bahwa busana ready to wear atau busana siap pakai tercipta sebagai hasil dari penerapan seragam perang dunia pertama. Pada dewasa ini, di Indonesia busana ready to wear terus dikembangkan seiring dengan berkembangnya industri fashion. Hal ini sesuai dengan visi pengembangan mode periode 2015-2019 yang dapat dilihat pada buku Rencana Pengembangan Mode Nasional 20152019, yang salah satunya yaitu berfokus pada ready to wear.

Busana ready to wear yang memiliki daya tarik dapat meningkatkan minat konsumen untuk membeli. Daya tarik busana ready to wear bisa didapatkan dari kain yang digunakan maupun penggunaan teknik aplikasi pada busana. Teknik aplikasi yang digunakan pada busana ready to wear di Indonesia, antara lain dengan menggunakan teknik cutting pada busana ataupun penggabungan beberapa kain motif pada satu busana. Desainer yang gemar menggunakan kain tradisional pada busana yang dibuat, antara lain Iwan Tirta yang gemar menggunakan kain batik, Lulu Lutfi Labibi dengan kain Lurik, dan Didiet Mulyana dengan kain tenun tradisional dari berbagai daerah.

Kain tenun tradisional memiliki eksistensi yang lebih rendah jika dibandingkan dengan kain batik. Dilansir dari artikel kemenperin.go.id tentang Kementerian Perindustrian Fokus Branding Kain Tenun ${ }^{3}$, Kemenperin RI siap mempromosikan kain tenun yang menjadi ciri khas pakaian orang Indonesia, sebab selama ini keberadaan kain tenun masih kalah pamor dibandingkan kain batik (kemenperin.go.id). Kain tenun yang ada di Indonesia sangat beragam, hampir setiap daerah di Indonesia memiliki kain tenun tradisional tersendiri dengan motif yang beragam. Salah satu daerah yang menghasilkan kain tenun tradisional berada di pulau Jawa, di daerah Jawa Tengah yaitu pada kota Jepara. Kain tenun yang dihasilkan di Jepara adalah kain tenun Troso. Sesuai dengan namanya, kain tenun Troso merupakan kain tenun ikat yang dibuat di desa Troso, Jepara, Jawa Tengah. Kain tenun Troso menggunakan stilasi hasil adaptasi motif-motif daerah lainnya untuk dijadikan sebagai sumber motif, seperti motif Toraja, NTT, Kalimantan, Bali dan lain sebagainya. 
Selain menggunakan penggabungan kain, teknik aplikasi lain yang sering digunakan pada busana meliputi aplikasi printing kain, bordir, pemasangan payet dan aplikasi sulam. Teknik aplikasi lain yang dapat dieksplor penggunaannya dalam busana ready to wear adalah aplikasi smock, dekonstruksi kain, ikat mengikat atau makrame. Teknik aplikasi ikat mengikat atau yang lebih dikenal dengan teknik makrame adalah teknik ikat mengikat yang akan menghasilkan simpul. Nilai seni yang dihasilkan teknik makrame tinggi, hal ini dikarenakan pada saat proses pembuatan dilakukan secara manual. Teknik makrame dalam pembuatannya menggunakan benang ataupun bahan lain seperti tali atau potongan kain sebagai bahan utama.

Dilansir dari artikel merdeka.com tentang 6 Macam Simpul Makrame, Dapat Menjadi Kerajinan Tangan Estetik ${ }^{4}$ pengaplikasian teknik makrame sering kali digunakan pada produk-produk rumah tangga seperti ikat pinggang, penghias gerabah atau keramik, tas, hiasan dinding, keranjang tanaman, gorden, taplak meja dan sebagainya. Pengaplikasian kain tenun troso dan teknik makrame dapat dieksplor penggunaannya dalam busana.

Berdasarkan uraian latar belakang tersebut, maka dilakukan pembuatan busana ready to wear sebanyak tiga produk dengan tampilan yang berbeda tetapi masih dalam satu tema, menggunakan kain tenun Troso dan makrame.

\subsection{Identifikasi Masalah}

Berdasarkan uraian latar belakang yang telah dipaparkan di atas, penetapan identifikasi masalah perlu dilakukan untuk mengetahui kemungkinan masalah selama proses pembuatan busana. Berikut merupakan identifikasi masalah yang ditetapkan :
1.Bagaimana pengaplikasian kain tenun Troso pada busana ready to wear?

2.Apakah jenis simpul makrame yang cocok digunakan dalam busana ready to wear sebagai salah satu aplikasi busana?

3.Bagaimana tanggapan masyarakat terhadap harga jual yang ditetapkan pada busana ready to wear yang menggunakan kain tenun Troso dan aplikasi makrame?

\subsection{Maksud dan Tujuan}

Maksud dari pembuatan busana ready to wear ini adalah untuk memberikan alternatif baru penggunaan kain tradisional nusantara dan teknik makrame dalam busana ready to wear sehingga dapat menambah nilai estetika. Tujuan penelitian ini yaitu mengangkat nilai kain tenun Troso dari Jepara dan mengeksplorasi jenis simpul makrame yang dapat digunakan untuk aplikasi busana ready to wear, serta mengetahui harga jual yang sesuai untuk busana tersebut agar dapat menjadi referensi bagi pengrajin maupun akademisi dalam mengekplorasi ide.

\subsection{Manfaat Penelitian}

Manfaat yang akan diperoleh dari hasil penelitian ini bagi para pelaku industri (IKM Pertenunan) adalah meningkatkan permintaan produk kain tenun Troso yang disebabkan semakin variatifnya alternatif penggunaan kain tenun Troso pada busana ready to wear maupun jenis busana lainnya. Manfaat bagi masyarakat pada umumnya yaitu membuka wawasan penggunaan kain tenun troso dan aplikasi makrame dalam pembuatan produk busana ready to wear, sehingga dapat meningkatkan minat masyarakat dalam mengembangkan atau diversifikasi produk dari kain tenun Troso, bahkan menginspirasi pembuatan busana 
dengan kain tenun ikat dari daerah lainnya

\section{BAHAN DAN METODE}

\subsection{Alat dan Bahan}

Proses pembuatan aplikasi makrame dan pembuatan busana membutuhan berbagai alat dan bahan. Alat dan bahan yang diperlukan pada pembuatan makrame yaitu benang makrame, pita ukur dan gunting kain. Pencelupan zat warna pada makrame menggunakan alat dan bahan yaitu gelas breaker, pengaduk, termometer, air, zat warna direk, $\mathrm{NaCl}$ dan Soda Ash. Proses pembuatan busana menggunakan peralatan menjahit seperti mesin jahit, gunting, pita ukur, mesin obras, kertas pola, alat tulis, kapur jahit dan jarum pentul. Bahan yang digunakan yaitu kain tenun Troso, kain tenun polos dengan nama dagang Katun Ima Premium, interlining, zipper dan kancing. Pemilihan kain katun Ima Premium didasari pada hasil uji karakteristik kain, kenampakan yang baik, serta sifat tidak mudah kusutnya.

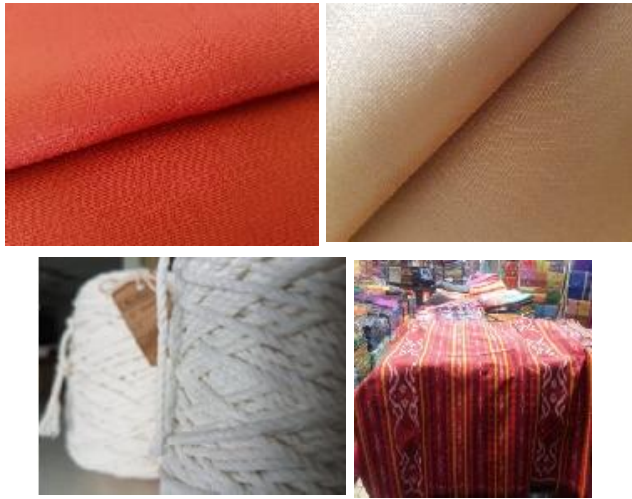

Gambar 1. Material Utama Produk Ready to Wear dengan Kain Tenun Troso

\subsection{Metode}

Penelitian ini merupakan pembuatan produk fashion dari kain tenun Troso dan kain tenun polos sebagai variasi dengan tambahan simpul makrame yang terbuat dari tali katun, sehingga metodologi penelitian yang digunakan adalah pembuatan produk, seperti terlihat pada alur berikut ini :

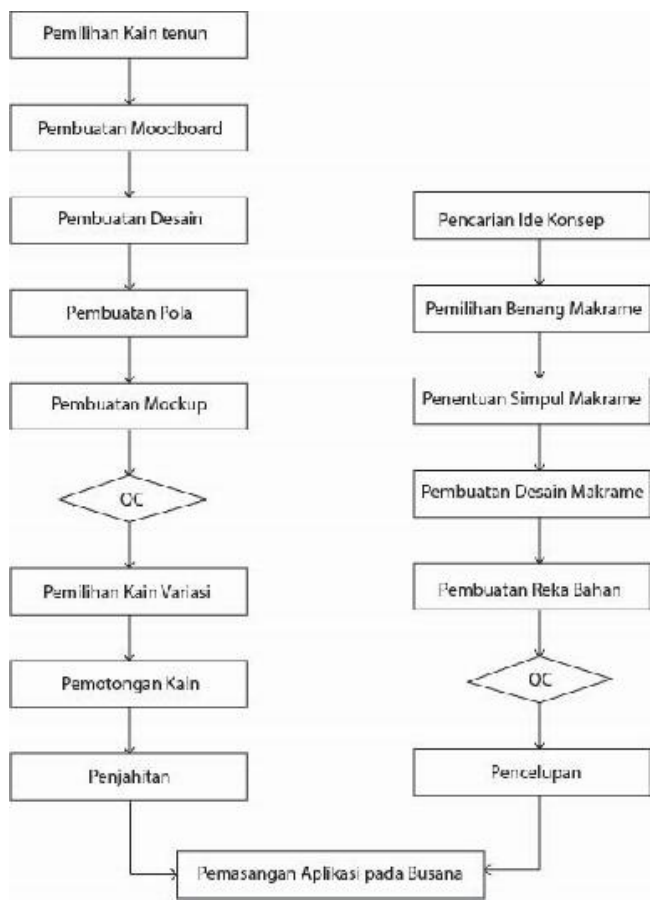

Gambar 2. Diagram Alir Produksi Busana

\section{HASIL}

Proses pemilihan kain tenun Troso dilaksanakan secara langsung melihat di pasaran, motif tenun yang menarik dan mempunyai nilai jual baik, serta memiliki desain geometris seperti pada recana desain ready to wear yang akan dibuat. Pada proses selanjutnya yaitu pembuatan moodboard, analisa pada warna dan unsur motif dari kain tenun Troso dikolaborasikan dengan trend forecasting Singularity 2019/2020 dengan sub tema "Svarga"5. Konten moodboard diisi dengan visual bergaya etnik yang sesuai dengan sub tema "Svarga", dilengkapi dengan warnawarna yang akan digunakan pada koleksi busana. Berikut moodboard yang dapat dilihat pada Gambar 3. 


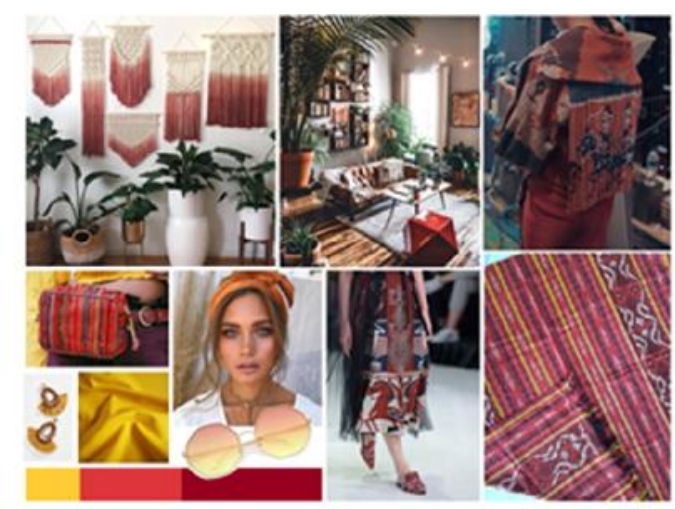

Gambar 3. Moodboard

Desain alternatif yang dibuat adalah sebanyak 5 desain, kemudian dipilih kembali untuk menentukan tiga desain yang akan diproduksi. Skema warna dan peletakan motif didasarkan pada teori color scheme ${ }^{678}$. Berikut adalah tiga buah gambar desain terpilih dapat dilihat pada Gambar 4 di bawah ini.

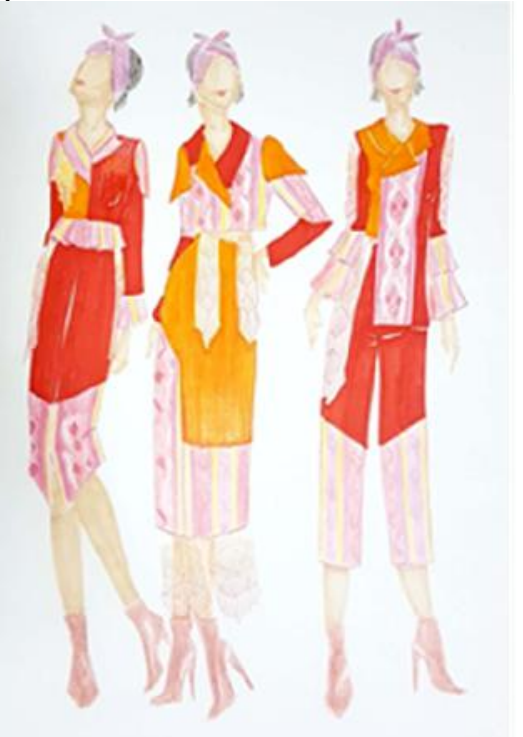

Gambar 4. Rancangan Desain Produk Ready to wear

Proses produksi mencakup pembuatan pola, pemotongan serta proses penjahitan dan finishing. Produk ready to wear yang telah melalui proses produksi kemudian dilakukan proses pemotretan produk yang bertujuan sebagai dokumentasi dan media promosi pada target pasar. Hasil pemotretan produk dapat dilihat pada Gambar 5, 6 dan 7.

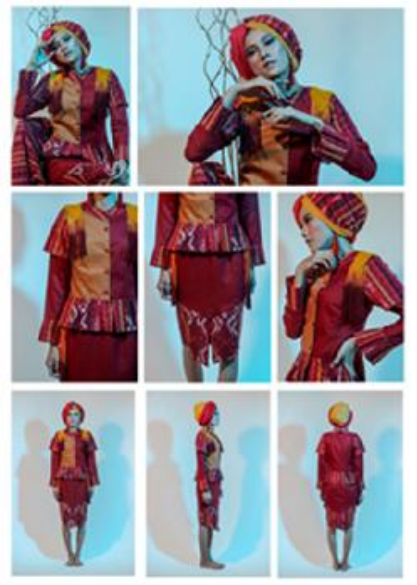

Gambar 5. Produk Troso 1

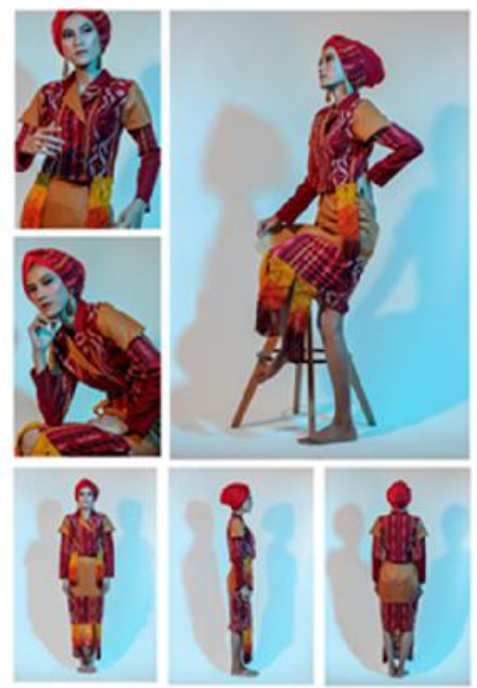

Gambar 6. Produk Troso 2 


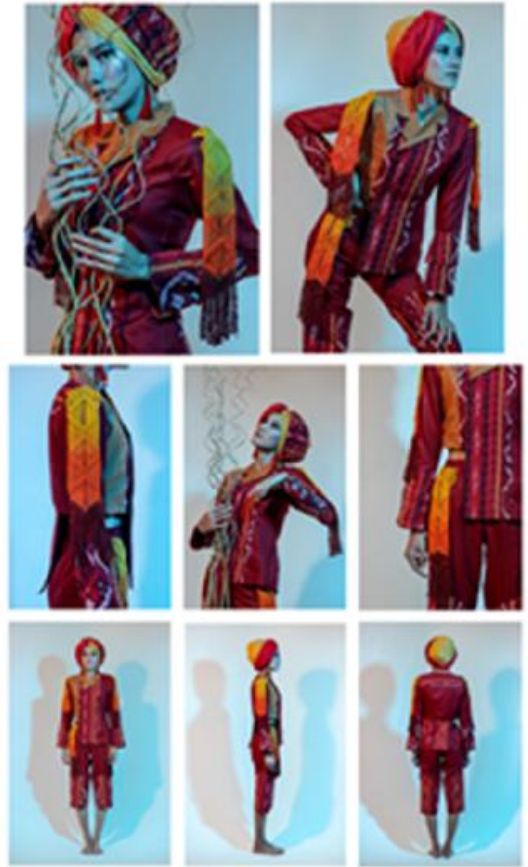

Gambar 7. Produk Troso 3

Penentuan jenis kain pada penelitian ini melalui pengujian karakteristik kain yang diadopsi dari SNI 0051:2008 Kain Tenun untuk Kemeja ${ }^{9}$. Maksud dilakukannya pengujian ini adalah untuk memperkuat data bahwa pemilihan kain sesuai dengan tujuan akhir sebagai pakaian ready to wear. Hasil pengujian tersaji pada Tabel 1.

\subsection{Perhitungan Biaya Produksi}

Sebuah produk perlu melalui survei terhadap minat pasar dan kelayakan harga jual atas produk yang telah dibuat dari konsumen. Survei dilakukan melalui kuesioner online, yaitu google form. Perhitungan Harga Pokok Produksi (HPP) dilakukan untuk menentukan harga jual yang sesuai dengan produk yang dibuat. Komponen perhitungan HPP yaitu, biaya bahan baku terdiri atas kain, aksesoris, tali makrame, alat dan bahan pewarnaan, biaya tenaga kerja terdiri atas jasa jahit dan jasa pembuatan makrame, serta biaya desain busana. Penentuan besaran laba yang diperoleh didasari oleh jenis busana ready to wear yang dapat diproduksi massal, namun dengan pengaplikasian kerajinan tangan berupa makrame dan pewarnaan gradasi sehingga ditetapkan nilai laba $40 \%$ dari HPP. Perhitungan biaya produk tersaji pada Tabel 2, 3 dan 4. 
Tabel 1 Hasil Pengujian Kain

\begin{tabular}{|c|c|c|c|c|c|c|}
\hline No & \multicolumn{2}{|l|}{ Test Parameter } & Nilai & Kain Tenun & Kain Tenun & Keterangan \\
\hline \multirow[t]{2}{*}{1.} & \multirow[t]{2}{*}{$\begin{array}{l}\text { Kekuatan Tarik cara Pita } \\
\text { Tiras }\end{array}$} & Lusi & $11,0 \mathrm{~kg}$ & $\begin{array}{c}31,20 \mathrm{~kg} \\
1,79 \% \\
\end{array}$ & $\begin{array}{c}27,68 \mathrm{Kg} \\
9,10 \% \\
\end{array}$ & Sesuai SNI \\
\hline & & Pakan & $11,0 \mathrm{~kg}$ & $\begin{array}{c}31,18 \mathrm{Kg} \\
3,42 \%\end{array}$ & $\begin{array}{c}19,12 \mathrm{Kg} \\
5,21 \%\end{array}$ & Sesuai SNI \\
\hline \multirow[t]{2}{*}{2.} & \multirow[t]{2}{*}{ Kekuatan Jahitan } & Lusi & $8,0 \mathrm{~kg}$ & $40,50 \mathrm{Kg}$ & $28,08 \mathrm{Kg}$ & Sesuai SNI \\
\hline & & Pakan & $8,0 \mathrm{~kg}$ & $9,25 \mathrm{Kg}$ & $14,25 \mathrm{Kg}$ & Sesuai SNI \\
\hline \multirow[t]{2}{*}{3.} & \multirow{2}{*}{$\begin{array}{l}\text { Kekuatan Sobek cara } \\
\text { Elmendorf }\end{array}$} & Lusi & $0,7 \mathrm{~kg}$ & $5,35 \mathrm{Kg}$ & $4,05 \mathrm{Kg}$ & Sesuai SNI \\
\hline & & Pakan & $0,7 \mathrm{~kg}$ & $5,83 \mathrm{Kg}$ & $2,02 \mathrm{Kg}$ & Sesuai SNI \\
\hline \multirow[t]{3}{*}{4.} & \multirow[t]{3}{*}{ Kekakuan } & Lusi & - & $8,02 \mathrm{mg} . \mathrm{cm}$ & $5,77 \mathrm{mg} . \mathrm{cm}$ & \multirow{3}{*}{$\begin{array}{l}\text { Tidak diuji } \\
\text { pada SNI }\end{array}$} \\
\hline & & Pakan & - & $6,79 \mathrm{mg} \cdot \mathrm{cm}$ & $16,15 \mathrm{mg} . \mathrm{cm}$ & \\
\hline & & Total & - & $7,38 \mathrm{mg} . \mathrm{cm}$ & $9,65 \mathrm{mg} . \mathrm{cm}$ & \\
\hline \multirow[t]{2}{*}{5.} & \multirow[t]{2}{*}{ Stabilitas Dimensi } & Lusi & $2,00 \%$ & - & $-6,73 \%$ & $\begin{array}{l}\text { Kain Troso } \\
\text { Mengkeret }\end{array}$ \\
\hline & & Pakan & $2,00 \%$ & - & $-4,30 \%$ & $\begin{array}{l}\text { Kain Troso } \\
\text { Mengkeret }\end{array}$ \\
\hline \multirow[t]{3}{*}{6.} & \multicolumn{6}{|l|}{$\begin{array}{l}\text { Tahan Luntur terhadap } \\
\text { Pencucian }\end{array}$} \\
\hline & a. Perubahan Warna & & 4 & 4 & $4-5$ & Sesuai SNI \\
\hline & $\begin{array}{ll}\text { a. } & \text { Penodaan terhadap: } \\
\text { - } & \text { Wool } \\
\text { - } & \text { Akrilik } \\
\text { - } & \text { Poliester } \\
\text { - } & \text { Nilon } \\
\text { - } & \text { Kapas } \\
\text { - } & \text { Asetat Rayon }\end{array}$ & & $\begin{array}{l}3-4 \\
3-4 \\
3-4 \\
3-4 \\
3-4 \\
3-4\end{array}$ & $\begin{array}{c}4-5 \\
4-5 \\
4 \\
3-4 \\
4 \\
4\end{array}$ & $\begin{array}{c}4-5 \\
4-5 \\
4 \\
3-4 \\
2 \\
4\end{array}$ & $\begin{array}{c}\text { Kain Troso } \\
\text { luntur pada } \\
\text { penodaan } \\
\text { kapas }\end{array}$ \\
\hline
\end{tabular}

Tabel 2. Perhitungan biaya Produk Troso 1

\begin{tabular}{|c|l|cr|}
\hline No & Keterangan & \multicolumn{2}{|c|}{ Harga } \\
\hline $\mathbf{1}$ & $\begin{array}{l}\text { Total biaya } \\
\text { bahan baku }\end{array}$ & $\mathrm{Rp}$ & $240.000,00$ \\
\hline $\mathbf{2}$ & $\begin{array}{l}\text { Total biaya } \\
\text { tenaga kerja }\end{array}$ & $\mathrm{Rp}$ & $325.000,00$ \\
\hline $\mathbf{3}$ & $\begin{array}{l}\text { Biaya desain } \\
\text { busana }\end{array}$ & $\mathrm{Rp}$ & $150.000,00$ \\
\hline \multirow{2}{*}{$\begin{array}{c}\text { Total HPP } \\
\text { Keuntungan 40\% } \\
\text { J umlah }\end{array}$} & $\mathrm{Rp}$ & $715.000,00$ \\
$\mathrm{Rp}$ & $286.000,00$ \\
$\mathrm{Rp}$ & $1.001 .000,00$ \\
\hline
\end{tabular}

Tabel 3. Perhitungan biaya Produk Troso 2

\begin{tabular}{|c|c|c|c|}
\hline No & Keterangan & & Harga \\
\hline 1 & $\begin{array}{l}\text { Total biaya } \\
\text { bahan baku }\end{array}$ & $\mathrm{Rp}$ & $275.000,00$ \\
\hline 2 & $\begin{array}{l}\text { Total biaya } \\
\text { tenaga kerja }\end{array}$ & $\mathrm{Rp}$ & $350.000,00$ \\
\hline 3 & $\begin{array}{l}\text { Biaya desain } \\
\text { busana }\end{array}$ & $\mathrm{Rp}$ & $150.000,00$ \\
\hline $\mathrm{Ke}$ & $\begin{array}{l}\text { Total HPP } \\
\text { intungan } 40 \% \\
\text { J umlah }\end{array}$ & $\begin{array}{l}\mathrm{Rp} \\
\mathrm{Rp} \\
\mathrm{Rp}\end{array}$ & $\begin{array}{r}775.000,00 \\
310.000,00 \\
1.085 .000,00\end{array}$ \\
\hline
\end{tabular}

Tabel 4. Perhitungan biaya Produk Troso 3

\begin{tabular}{|c|c|c|c|}
\hline No & Keterangan & \multicolumn{2}{|r|}{ Harga } \\
\hline 1 & $\begin{array}{l}\text { Total biaya } \\
\text { bahan baku }\end{array}$ & $\mathrm{Rp}$ & $275.000,00$ \\
\hline 2 & $\begin{array}{l}\text { Total biaya } \\
\text { tenaga kerja }\end{array}$ & $\mathrm{Rp}$ & $325.000,00$ \\
\hline 3 & $\begin{array}{l}\text { Biaya desain } \\
\text { busana }\end{array}$ & $\mathrm{Rp}$ & $150.000,00$ \\
\hline & $\begin{array}{l}\text { Total HPP } \\
\text { untungan } 40 \% \\
\text { J umlah }\end{array}$ & $\begin{array}{l}\mathrm{Rp} \\
\mathrm{Rp} \\
\mathrm{Rp}\end{array}$ & $\begin{array}{r}750.000,00 \\
300.000,00 \\
1.050 .000,00\end{array}$ \\
\hline
\end{tabular}

\subsection{Survei Ready to Wear Troso}

Melalui kuesioner yang telah diisi oleh sebanyak 106 orang responden, diperoleh hasil persentase kelayakan harga jual produk ready to wear ini. Berikut merupakan data survei yang tersaji pada Gambar 8. 


\section{INFORMASI SINGKAT RESPONDEN}

Jenis Kelamin

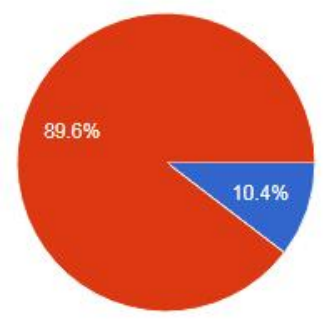

Pekerjaan

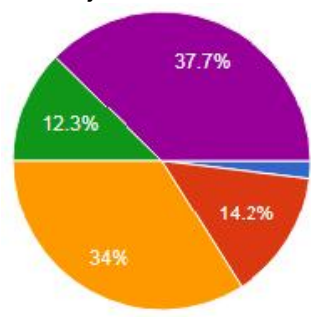

Usia

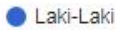

- Perempuan

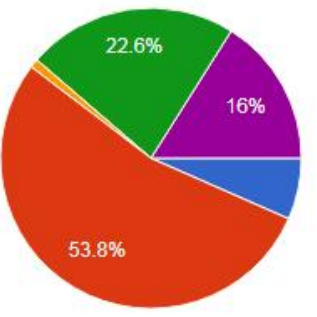

Penghasilan per bulan

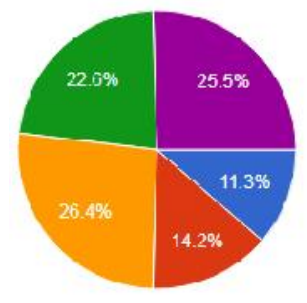

- Mahasiswa

Karyawan (swasta)

- Pegawa Negeri

- Wiraswasta

- Ibu Rumah Tangga
$18-25$ tahun

$26-35$ tahun

36 - 40 tahun

- 41 - 50 tahun

$>50$ tahun
- Rp 2.500 .000

Ro $2.600 .000-R 04.000 . C 00$

- Rp 4.100.000-Rp 6.000.CO0

Rp 6. $100.000-R p 8.000 . C 00$

= $R p 8.000 .000$

\section{KELAYAKAN HARGA}

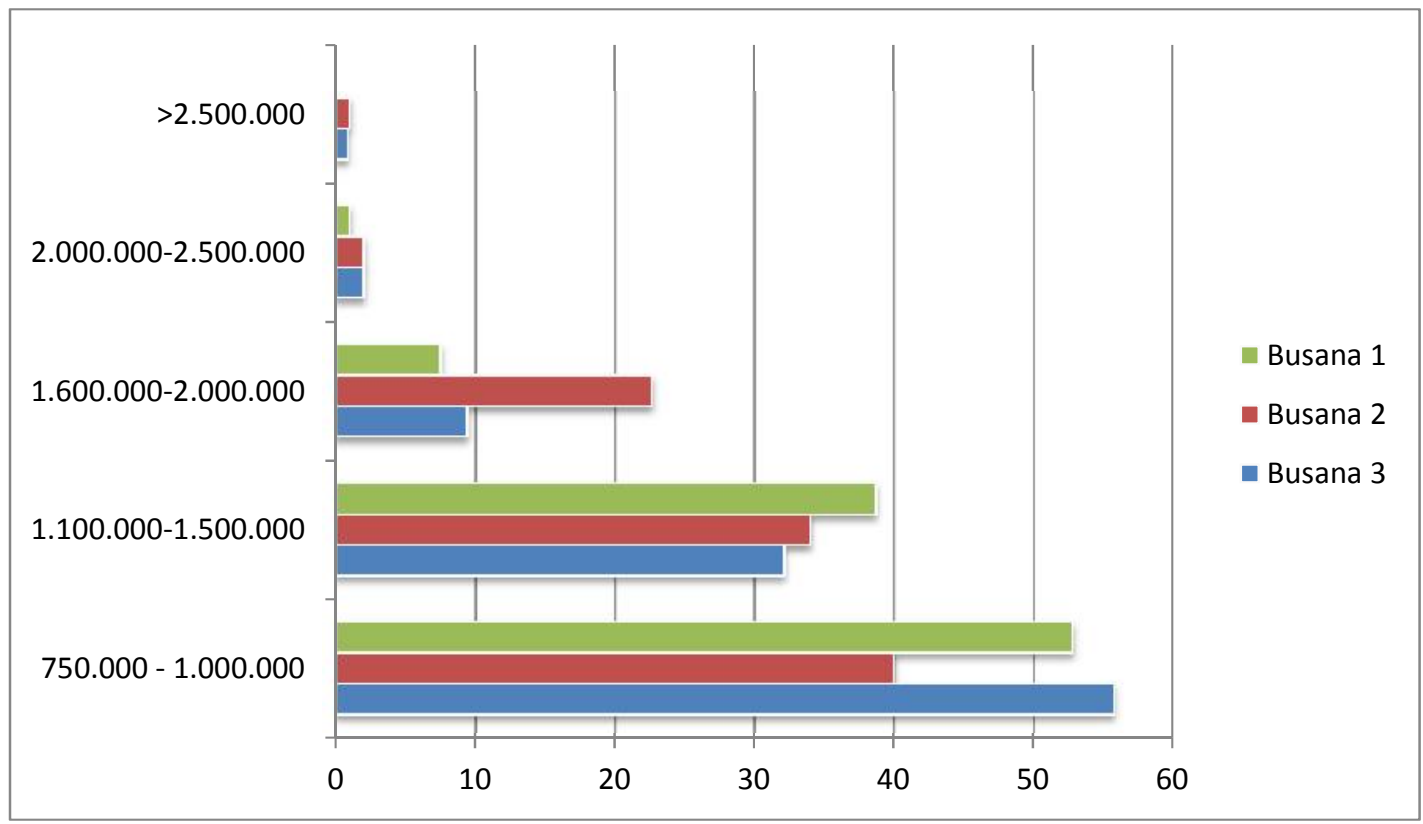

Gambar 8 Diagram Survey Busana R eady to Wear Troso 


\section{PEMBAHASAN}

Pemilihan kain tenun troso dilakukan secara langsung di pasar, yaitu motif tenun yang menarik dan mempunyai nilai jual baik. Pemilihan motif dan warna kain tenun juga disesuaikan dengan tren fashion 2019/2020 sub tema "Svarga", yaitu warna maroon dan kuning tua. Rancangan bentuk makrame mendasari pemilihan motif tenun Troso, yaitu bentuk geometris belah ketupat. Kriteria pemilihan kain tenun Troso tersebut merujuk pada salah satu motif kain tenun Troso yaitu kain dengan motif stilasi yang diadaptasi dari kain tenun Toraja.

Proses pembuatan moodboard merujuk pada tren fashion 2019/2020 yang ditetapkan oleh Indonesia Trend Forecast. Trend forecast Indonesia di tahun 2019/2020 berjudul Singularity memiliki 4 sub tema, yaitu "Exuberant, Neo Medieval, Svarga dan Cortex"5. Sub tema "Svarga" dipilih sesuai dengan penggunaan kain tenun Troso untuk pembuatan busana bergaya etnik.

Konten moodboard diisi dengan gambar yang menjadi representasi visual ide, diantaranya contoh busana bergaya etnik, simpul makrame, dan aksesoris pendukung. Gambar suasana etnik yang sesuai dengan sub tema "Svarga", serta warna-warna yang akan digunakan pada koleksi busana turut disertakan pada moodboard sebagai pedoman pembuatan desain busana.

Pembuatan desain sebanyak 5 buah dilakukan dengan memasukkan motif serta warna kain troso yang telah dipilih. Proses kurasi kemudian dilakukan untuk menentukan 3 buah desain yang akan diwujudkan menjadi koleksi busana ready to wear.

Tahap berikutnya yang dilakukan adalah melakukan eksplorasi dalam memilih tali makrame dan menentukan simpul makrame yang akan digunakan sebagai variasi busana. Pemilihan tali makrame didasari pada beberapa pertimbangan, diantaranya adalah komposisi material, jenis lilitan, kekuatan tali, ukuran dan tekstur tali makrame. Tali makrame berasal dari beragam bahan, mulai dari katun, nilon, tali rami, polyester, kulit, hingga linen. Pada penelitian ini dipilih jenis tali berbahan katun untuk memudahkan dalam proses pencelupan dengan zat warna untuk menghasilkan efek gadrasi atau ombre. Resep bahan pencelupan yaitu :

- $\quad$ Zat Warna Direk 4 gram

- $\quad \mathrm{NaCl} 30$ gram

- $\quad$ Soda Ash 4 gram

- $\quad$ Air hingga 1 liter

Terdapat tiga jenis lilitan pada tali makrame seperti pada artikel "Mengenal Kerajinan Makrame" yang dilansir oleh rekreative.com (2019) ${ }^{10}$, yaitu tali lilitan berkepang, satu lilitan dan tiga lilitan. Tali lilitan berkepang cukup kaku dan kuat, sama halnya dengan tali tiga lilitan. Tali tiga lilitan memiliki struktur yang terlihat jelas dan rapi, sehingga dalam penelitian ini dipilih tali dengan jenis tiga lilitan. Eksplorasi dalam pemilihan jenis dan ukuran tali dilakukan dengan membandingkan tali katun berdiameter $2 \mathrm{~mm}$ dan $4 \mathrm{~mm}$ berjenis tiga lilitan. Kedua variasi ukuran tali diuji coba dengan membuat simpul makrame yang sama untuk memperoleh perbandingan hasil kelangsaian makrame yang sesuai dengan busana. Setelah proses percobaan dilakukan, tali katun berdiameter $2 \mathrm{~mm}$ dipilih karena kelangsaiannya sesuai dengan yang diinginkan.

Simpul yang akan digunakan merupakan jenis simpul yang sebelumnya telah dieksplorasi bentuknya, yaitu simpul kordon, simpul jangkar, dan simpul mati seperti pada Gambar 9 berikut. 


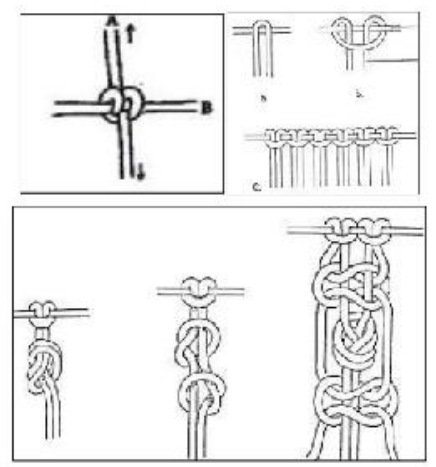

Gambar 9. Simpul Kordon, Simpul Jangkar dan Simpul Mati

Berdasarkan langkah-langkah pembuatan makrame oleh Peggy Anderson pada tulisan "Macrame Knots and Projects"11, pembuatan reka bahan makrame diawali dengan mempersiapkan benang penyangga dan benang garapan. Benang penyangga adalah benang yang diletakksan horizontal sebagai gantungan awal kerangka makrame, sedangkan benang garapan adalah benang yang disimpulkan pada benang penyangga secara berjajar untuk kemudian diimpulkan satu sama lain. Benang penyangga dipotong dengan ukuran yang disesuaikan dengan kebutuhan. Benang dipotong kembali dan dijadikan sebagai benang garapan yang ukuran dan panjangnya pun disesuaikan dengan kebutuhan. Setelah benang penyangga dan garapan selesai dipotong, benang akan mulai disimpul menjadi makrame. Makrame yang telah dibuat kemudian diwarnai dengan proses pemasakan bersuhu $80^{\circ} \mathrm{C}$. Proses dilakukan dengan menggantung makrame secara vertikal dengan memanfaatkan hukum kapilaritas untuk memperoleh efek warna ombre.

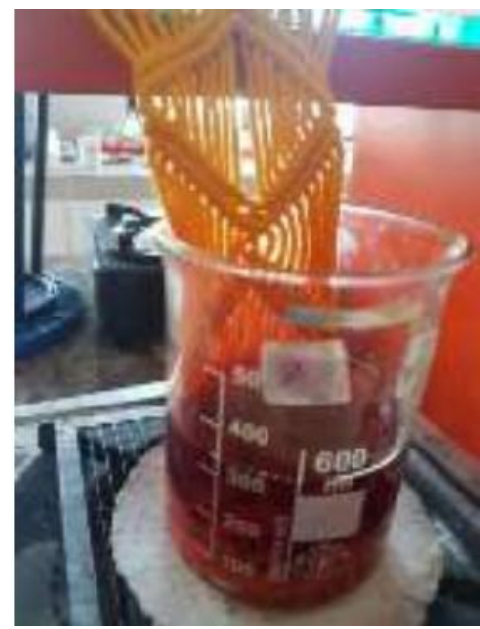

Gambar 10. Pewarnaan Ombre pada Makrame

Pemasangan aplikasi makrame dilakukan setelah busana selesai diproduksi menerapkan pemasangan dengan jahitan tangan. Pemasangan makrame disesuaikan dengan rancangan busana yang telah dibuat.

Dalam menilai kelayakan harga jual produk ready to wear, responden terdiri atas $10,4 \%$ laki-laki dan $89,6 \%$ adalah perempuan. Rentang usia terbanyak yaitu 26-35 tahun sebanyak 53,8\% dengan variasi penghasilan per bulan. Hasil survei diperoleh bahwa lebih dari $74,5 \%$ menyatakan sependapat dengan harga jual yang ditetapkan, bahkan 8,5-25,5\% menilai produk layak diberi harga lebih tinggi dari harga jual.

\section{KESIMPULAN DAN SARAN}

Berdasarkan hasil penelitian berupa pembuatan produk, kesimpulan yang dapat diambil yaitu penggunaan kain tenun Troso pada ready to wear dapat menjadi alternatif pilihan busana untuk berbagai kesempatan, dan dapat menjadi salah satu usaha pengembangan pengenalan kain tenun etnik di Indonesia untuk lebih dikenal masyarakat. Beberapa sifat pada tenun Troso yang perlu diantisipasi dalam 
pembuatan busana seperti mengkeret dan luntur pada penodaan kapas dapat diantisipasi dengan melakukan pencucian kain terlebih dahulu sebelum proses produksi busana.

Pengaplikasian simpul makrame dapat digunakan pada busana ready to wear untuk menambah estetika dan unsur etnik pada busana, khususnya pengaplikasian simpul kordon, simpul jangkar dan simpul mati yang mudah dibuat. Survei yang diadakan untuk menilai kelayakan harga pada tiga buah produk, diperoleh hasil bahwa ketertarikan pada produk bergaya etnik dengan sentuhan kerajinan tangan digemari oleh masyarakat, dengan besarnya jumlah tanggapan responden yang sependapat dengan harga jual yaitu lebih dari $74,5 \%$.

Saran yang dapat dilakukan untuk penelitian berikutnya adalah eksplorasi penggunaan kain tenun troso misalnya dipadukan dengan motif lain, eksplorasi jenis simpul makrame dan cara pengaplikasian pada busana selain menggunakan cara dijahit secara konvensional menggunakan jahit tangan.

Eksplorasi pada penelitian ini dapat menginspirasi pembuatan busana dengan kain tenun dari daerah lainnya. Penggunaan kain tenun Troso pada penelitian berikutnya dapat dilakukan dengan menyesuaikan pada trend forecast di masa yang akan datang.

\section{UCAPAN TERIMA KASIH}

1. Politeknik STTT Bandung melalui UP2M atas dukungan material sehingga penelitian ini dapat dihasilkan 2. Staf Laboratorium Evaluasi Fisika Tekstil dan Evaluasi Kimia Tekstil,atas bantuan dalam melakukan evaluasi fisika kain dan evaluasi ketahanan luntur terhadap pencucian untuk busana ready to wear Troso.

3. Fitry Fauziah atas bantuannya menjadi model pemotretan busana ready to wear Troso, Annisa Army atas bantuannya menjadi fotografer pemotretan busana ready to wear Troso dan Salma Destryanda atas bantuannya menjadi tata rias pemotretan busana ready to wear Troso. 


\section{DAFTAR PUSTAKA}

1. Monica, D. Penting! Aneka Istilah Fashion \& Artinya.

www.fimela.com/fashion/read/3506435/penting-aneka-istilah-fashion-ampartinya (2011).

2. Waddell, G. How Fashion Works: Couture, Ready-to-Wear and Mass Production. (John Wiley and Sons Ltd, 2004).

3. Kemenperin RI. Kementerian Perindustrian Fokus Branding Kain Tenun. kemenperin.go.id/artikel/16237/ghs (2016).

4. Lararenjana, E. 6 Macam Simpul Makrame. www.merdeka.com/jatim/6macam-simpul-makrame-dapat-menjadi-kerajinan-tangan-estetik-kln.html (2020).

5. Indonesia Trend Forecast. SING ULARITY. (BEKRAF, 2018).

6. Clarke, S. Textile Design: Portfolio Series. (Laurence King Publishing, 2011).

7. Darmaprawira W.A., S. Warna: Teori dan Kreativitas Penggunaannya. (Penerbit ITB, 2002).

8. Jenkyn Jones, S. Fashion Design. (Laurence King Publishing, 2005).

9. Badan Standarisasi Nasional. SNI 0051:2008 - Kain Tenun untuk Kemeja. (2008).

10. Zujajah, K. Mengenal Kerajinan Makrame. https://rekreartive.com/mengenalkerajinan-makrame/ (2020).

11. Anderson, P. \& Team. Macrame Knots and Project. (NDSU, 2003). 